\title{
Learning Social Sciences With Comic Strip
}

\author{
Ayok Ariyanto ${ }^{1}$, Sigit Dwi Laksana ${ }^{2}$ \\ Muhammadiyah University of Ponorogo, Indonesia ${ }^{1,2}$ \\ \{ayokariyanto@gmail.com ${ }^{1}$, sigitciovi@gmail. $\left.\mathrm{com}^{2}\right\}$
}

\begin{abstract}
Most of the problems occurring in learning especially on the subjects of social class, some students fully understand concrete examples that are in daily life, some of them do not realize that what happened to is an example of an of learning social class, in determining social level often teachers do not uses the media and media uses interesting can improve understanding students ( cognitive and student learning achievements, remember due to the media learning in this matter is media comic strip has an essential meaning in the education sector, success or failure teaching depend on the medium used. Social class is the subject having extensive scope knowledge; it is tough if only taught with the methods talk ordinary and are needed media will attract the interest of the student to study and better than lessons social class.
\end{abstract}

Keywords: Learning Social Sciences, Comic Strip

\section{Introduction}

Comic is the type of reading the most popular and interested in, not only by children, but teenagers and the adult love kind of this newly-opened reading, because in terms of view, story, and character of figures displayed in comic very interesting, reason that the world education started to develop on extracting media the cartoon into learning. Media comic plays an important role as the implement has function convey a message learning; in this context, learning refers a process communication between learning and source of learning (comic). Communication learns they shall walk with a maximum if message learning delivered clearly, coherentand interesting.

The comics have long been used in the world of education as a medium of instruction. Educators in America also creates comics in favor of educational curriculum[1]. Lots of advantages of comics such as research conducted by Thorndike, it is known that children who read comics more e.g.in a month at least one comic book, then the same with reading textbooks in each year, This has an impact on the student's reading skills and mastery of the vocabulary is much more from students who don't like comics [2].

As one of the visual media comic media certainly has advantages of its own if utilized in teaching and learning activities[3]. Excess media comics in teaching and learning activities including comics add vocabulary,readers, facilitate the protégés capture things or abstract formula which can develop an interest read the child and one of the areas of study another[4], the entire comic storyline on towards one thing namely goodness or other studies [2]. Another comic excess is serving contains visual elements and a powerful story. As if students (readers) feel the flow of the story. This was the inspiration for creating comics that contains subject matter, but from these advantages that poured, it turns out there is a negative influence that 
needs to be avoided,and it is the task of the teacher is to always educate and direct learners to positive things.

\section{Result and discussion}

\subsection{A Comic Strip Media in Their Experiences Social Studies}

Social science is the subject ofteaching at the level MI/Primary School, MTs/Junior High School, and MA/High School.Sometimes in an area of knowledge often occurs a term overlap each other, among other social science and social study, although in the term there is the same word that is " social," it has a distinct meaning.Social science is part of the studies social, according to nursid social science is a field - the field of science that studies man as a member of the community. While he defines social science as disciplined of science that studies behavior group mankind[5].

Social science social class is subjects who studies social life based on the study geography, economic, sociology, anthropology, state administration, and history[6]. Social class is a simplification of adaptation, selection, and the modification of the academic discipline of social science that ceremony was organized and served in a scientific and pedagogy[7]. Social class delights as by human life involving all behavior and needs [8]. In giving an understanding of subjects, social class teachers can benefit from various media.One of the media of learning that could be used in both social class is media comic.This media rarely used in the education world, if the media a picture,film, chart,and others have often used, then comic media are still very rare no one even use it.Comic media is a form of visual communication media who have the power to convey information is popularly and easily understandable.This was possible because the power of comic blends likeness and title, strung together in a plot a picture, making information more easily absorbed [9], [10].

Besides, the use of appropriate comic media will improve learning outcomes and make the learning process interesting and fun, can reduce misunderstandings and obscurity. There have been several studies on comic media that have been proven to improve student achievement as follows:

\subsection{Sones performing a study on comic image quality can help to improve the quality of learning:}

Sones' divides four hundred sixths to ninth grade students in two groups. Each group is balanced in the class division and its first group skills are treated to learning the story using a comic and the second using text only. After that, they were tested to find out the content of the story's learning. After a week, the process is changed, the first group is treated to text only while the second is given a comic. Then the two groups were tested again. Finally, Sones' concludes that the effect of the image seen in the first group gets a much higher value than in the second group. The second ducts turned out that the second group got much higher values than the first group [11].

Hutchinson found that $74 \%$ of teachers surveyed considered comics to help motivate learning achievement, while 79\% said comics "increased individual participation", one teacher even said that comics make learning easy[11].

Thorndike does research on children who love to read comics, that children who read comics more, for example in a month at least one comic book, then the same as reading textbooks in each year[2]. 
From several studies conducted by researchers from America, we can conclude that with the comic media in the learning process can improve student achievement and it has been proven. There are many benefits in comic media, besides those already explained by the researchers above, Etin Solihatin and Raharjo explain the use of media (comics) not only make the learning process more efficient but also help students absorb the study materials more deeply and intact [12].

Comics can also provide a longer learning achievement because the comic gives time to reader to pay more attention to detail images and text in the story. In contrast to the moving visual media like movies, comics provide enough time for readers to explore images and text in more detail. That way the information conveyed through the comic can be remembered for longer.

This is by IPS subjects that require a media that support the learning process especially on social matter, this material is studied in class IV, in this material, there are various explanations about various examples of social problems. This is very difficult for students because in addition to less interesting presentation plus the need to think broadly to learn this material. The Media Comics Strip can describe the situation or storyline that matches the material presented interestingly with the characters in the likes of children, but still, prioritize the education and students' understanding of the material.

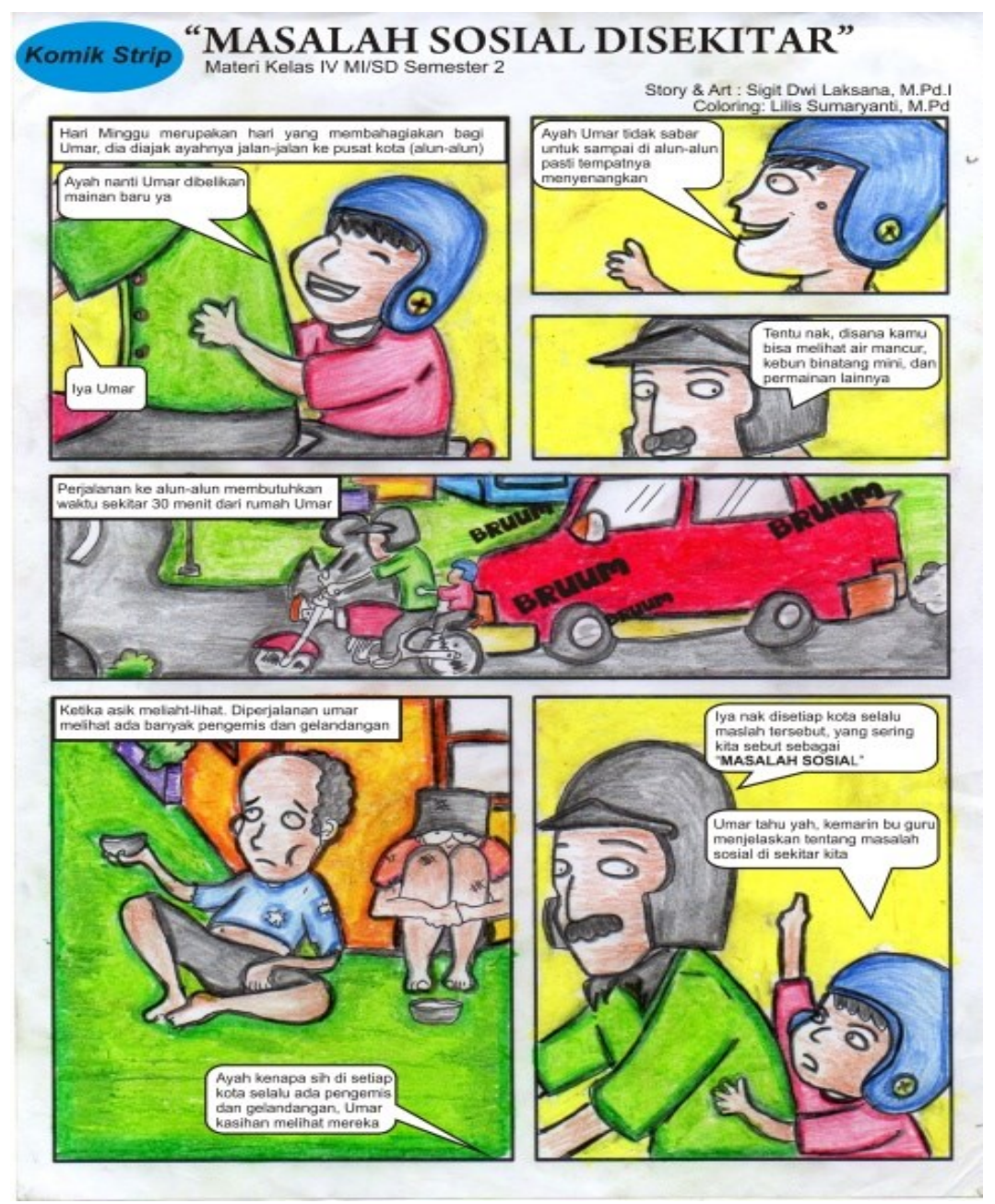



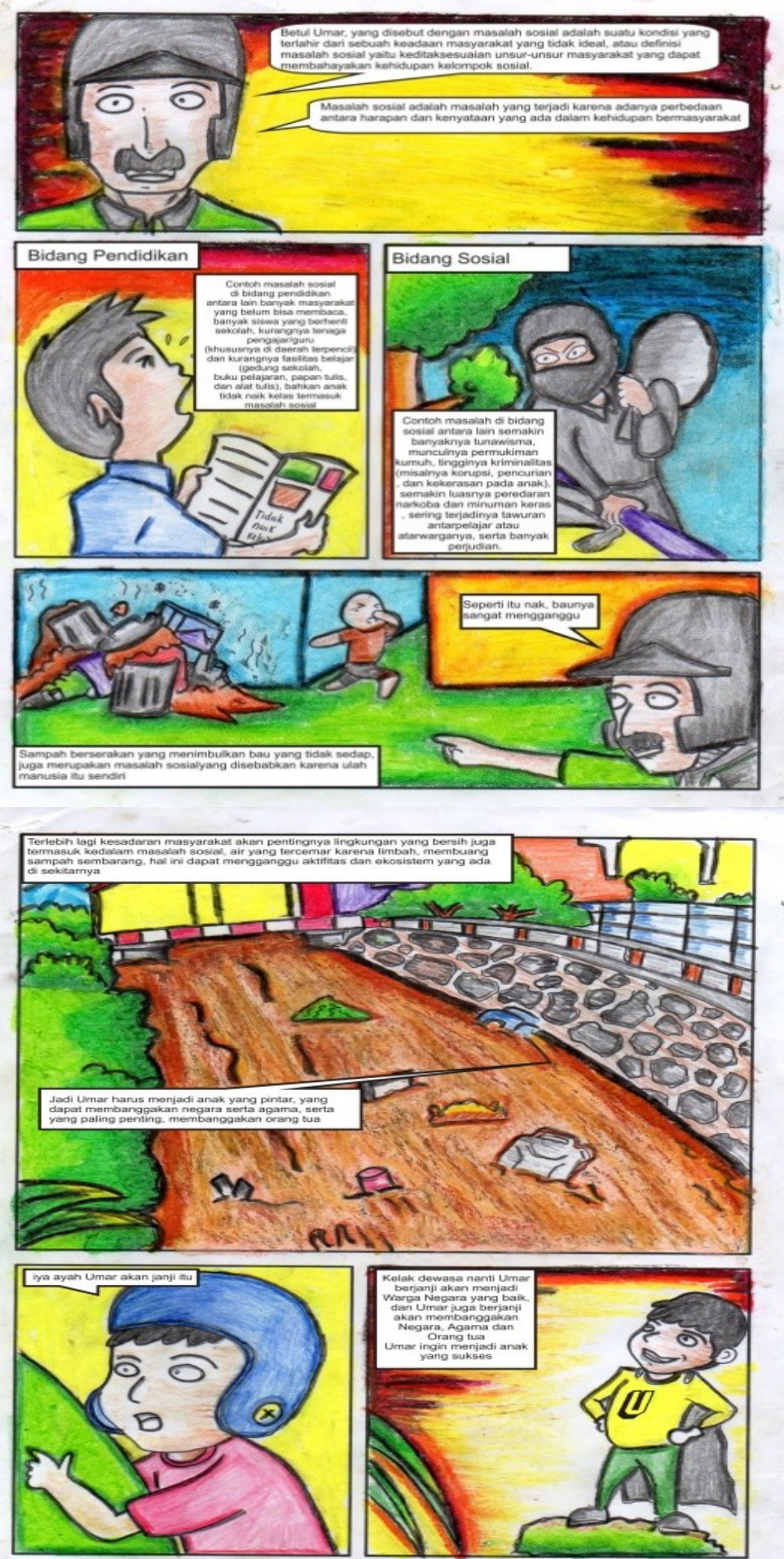


\section{Conclusion}

The existence of teachers as the spearhead of the success of learning cannot be separated from what the name of learning media, whether or not successful learning process depends on how innovative and intelligent the teacher in designing learning, for learning to be interesting and fun, then the teacher must be creative, making comic strips about the plot of the material, especially for materials that learning IPS With Comic Striprequire the breadth of thinking, such as Social Sciences, it is necessary to support media that is comic strip media, this media is a medium that has long existed but rarely used by teachers, because the limitations of the teacher. With the comic strip is expected to contribute to the world of education.

\section{References}

[1] A. Ikhwan, Pengembangan Kurikulum Pendidikan Agama Islam (PAI). Malang: Insan Cita Press dan STAIM Tulungagung, 2013.

[2] Daryanto, Media Pembelajaran. Bandung: Satu Nusa, 2010.

[3] A. Ikhwan, Filsafat Pendidikan Islam: Memahami Prinsip Dasar. Yogyakarta: Diandra Kreatif, 2018.

[4] A. Ikhwan, "Metode Simulasi Pembelajaran dalam Perspektif Islam," Istawa J. Pendidik. Islam, vol. 2, no. 2, pp. 1-34, 2017.

[5] S. Nurdin, Model pembelajaran yang memperhatikan keragaman individu siswa dalam kurikulum berbasis kompetensi. Ciputat: Quantum teachimg, 2005.

[6] D. I. Jaelani, "Manajemen Public Relations (Humas) Pendidikan Islam: Kajian Tematik Al Quran dan Hadits," Istawa J. Pendidik. Islam, vol. 3, no. 2, pp. 57-96, 2018.

[7] M. Lamont and V. Molnár, "The Study of Boundaries in the Social Sciences," Annu. Rev. Sociol., vol. 28, no. 1, pp. 167-195, Aug. 2002.

[8] N. Sumaatmadja, Metodolog: Pengajaran Ilmu Pengetahuan Sosial (IPS). Bandung: Alumni, 1980.

[9] E. Enawati and H. Sari, "PENGARUH PENGGUNAAN MEDIA KOMIK TERHADAP HASIL BELAJAR SISWA KELAS X SMA NEGERI 3 PONTIANAK PADA MATERI LARUTAN ELEKTROLIT DAN NONELEKTROLIT," J. Pendidik. Mat. dan IPA, vol. 1, no. 1, Mar. 2012.

[10] B. D. Jee and F. K. Anggoro, "Comic Cognition: Exploring the Potential Cognitive Impacts of Science Comics,” J. Cogn. Educ. Psychol., vol. 11, no. 2, pp. 196-208, 2012.

[11] H. D. Waluyanto, "KOMIK SEBAGAI MEDIA KOMUNIKASI VISUAL PEMBELAJARAN," Nirmana, vol. 7, no. 1, 2006.

[12] Hasan and Yusman.Basri.M, Petunjuk Guru Ilmu Pengetahuan Sosial 2. Jakarta: Balai Pustaka, 1998. 